\title{
REFERENCES AND RESOURCES
}

Allanson, B.R. and D. Baird (Eds.) Estuaries of South Africa. Cambridge University press, Cambridge.

Attwood, C.G., Mann, B.Q., Beaumont, J. and J.M. Harris. 1997. Review of the state of the Marine.

Barnes, K.N. 1998. The Important Bird Areas of Southern Africa. Birdlife South Africa, Johnannesberg.

Bek, D. and Taylor, I. 2001. Evaluation of Spatial Development Initiatives: case studies of the Maputo Development Corridor and the West Coast Investment Initiative. Development Policy Research Unit (DPRU), Working Paper No. 25, DPRU, University of Cape Town.

Berkes, F., Mahon, R., McConney, P., Pollnac, R. and R. Pomeroy. 2001. Managing smallscale fisheries: alternative directions and methods. IDRC CRDI, Canada.

Branch, G.M., Griffiths, C.L., Branch, M.L. and L.E. Beckley. 1994. Two Oceans: A Guide to the Marine Life of Southern Africa. David Philip Publishers, Cape Town.

Branch, G.M. and M. Branch. 1981. Living Shores of southern Africa. Struik, Cape Town.

Brundrit, G. B. 1995. Trends of southern African sea level: statistical analysis and interpretation. South African Journal of Marine Science 16, 9-17.

Cape Action Plan for the Environment 2000. A Biodiversity Strategy and Action Plan for the Cape Floral Kingdom. WWF South Africa.

Cape Sector Factsheet 2001. The environmental sector in the Western Cape. Cape Town: Wesgro.

Central Statistical Service, (CSS) 2000: October Household Survey 1998: Central Statistical Service, Pretoria.

Cicin-Sain, B. and R.W. Knecht. 1998. Integrated Ocean and Coastal Management Concepts 
and Practices. Island Press, Washington. pp. 517.

City of Cape Town, 2001. Cape Town's Economy: Current trends and future prospects. http://www.dti.co.za

Coastal Management Policy Programme [CMPP], 1998. Coastal Policy Green Paper: Towards Sustainable Coastal Development in South Africa, Cape Town: The Department of Environmental Affairs and Tourism.

Coastal Management Policy Programme (CMPP) 2000. White Paper for Sustainable Coastal Development in South Africa, Cape Town: The Department of Environmental Affairs and Tourism.

Convention and Protocol for Cooperation In the Protection and Development of the Marine and Coastal Environment of West and Central Africa (Abidjan Convention). 1981.

Convention for the Protection, Management and Development of the Marine and Coastal Environment of the Eastern African Region (Nairobi Convention). 1985.

Convention on Biological Diversity (CBD) Decision V/6 of the Fifth Meeting of the Conference of the Parties at the Convention on Biological Diversity (ecosystem approach). 1992.

Convention on Wetlands of International Importance (Ramsar Convention). 1971.

Council for the Environment, August 1991. A Policy for Coastal Zone Management in the Rep. of South Africa, Part 2: Guidelines for Coastal Land Use.

Day, J.H., and A.A. Balkema. 198. Estuarine Ecology with Particular Reference to Southern Africa. Netherlands.

Department of Environmental Affairs and Tourism 2000/2001 Annual Review.

DEAT (Department of Environmental Affairs and Tourism). March 1999. Draft White Paper for Sustainable Coastal Development in South Africa. 
DEAT. (Department of Environmental Affairs and Tourism) 2000. White Paper for Sustainable Coastal Development in South Africa.

DEAT. (Department of Environmental Affairs and Tourism) 2000. Sustainable Coastal Livelihoods Study, Volumes 1 and 2.

DEAT. (Department of Environmental Affairs and Tourism) 2000. Volume 2: Background Document to Sustainable Coastal Livelihoods Study.

Department of Land Affairs. White Paper on South African Land Policy. September 1998.

Environmental Evaluation Unit UCT. March 2003. Proceedings of workshops held in the Western Cape on the Coastal Management Programme.

GESAMP (IMO/FAO/UNESCO-IOC/WMO/WHO/IAEA/UN/UNEP Joint Group of experts on the Scientific Aspects of Marine Pollution). 2001. A Sea of Troubles. Rep.Stud. GESAMP No.70, 35pp.

Glavovic, B., 2000: Our Coast, Our Future: A New Approach to Coastal Management in South Africa, Cape Town: Department of Environmental Affairs and Tourism.

Glazewski, J. and Sowman, M., 1998: Institutional and legislative context and capacity for formulating and implementing the coastal management policy. Unpublished document, Coastal Management Policy Process.

Government Gazette. 2002. Mineral and Petroleum Resources Development Act. Republic of South Africa, Cape Town.

Harris, J. M., Sowman, M., Branch, G. M., Clark, B. M., Cockcroft, A. C., Coetzee, A. H., Hauck, M., Johnston, A., Kati-Kati, L., Maseko, Z., Salo, K., Sauer, W. H. H., SiqwanaNdulo, N., and J. Beaumont. 2002. The process of developing a management system for subsistence fisheries in South Africa: recognizing and formalizing a marginalized fishing sector in South Africa. South African Journal of Marine Science 24: 405-424.

Hauck, M. 1999. Seawatch: Civil Society's Role in Combating Environmental Crime. South African Journal of Environmental Law and Policy 6(1): 101-119. 
Hauck, M and R. Hector. 2000. An Analysis of Operation Neptune: Government's Response to Marine Poaching. (Occasional Paper Series). Cape Town: Institute of Criminology, University of Cape Town.

Hauck, M and N. A. Sweijd. 1999. A Case Study of Abalone Poaching in South Africa and its Impact on Fisheries Management. ICES Journal of Marine Science 56: 1024-1032.

Hauck, M. and M. Sowman. (eds.) 2003. Waves of Change: Coastal and Fisheries CoManagement in South Africa. University of Cape Town Press: Cape Town.

Heritage Lottery Fund. 1998. Conservation Plans for Historic Places.

Hockey, P.A.R. and G.M. Branch. 1997. Criteria, objectives and methodology for evaluating marine protected areas in South Africa. South African Journal of Marine Science 18: 369383.

Jackson, L.F. and S. Lipschitz. 1984. Coastal Sensitivity Atlas of Southern Africa. Department of Transport, South Africa.

Johannesburg Plan of Implementation. 2002.

Kerr, J.S. 2000. The Conservation Plan: A guide to the preparation of Conservation Plans for places of European cultural significance. National Trust of Australia (NSW), Sydney.

May, J., 2000. Poverty and Inequality in South Africa: Meeting the Challenge. J. May (Ed.), David Philip, Cape Town.

Mariculture Section Marine and Coastal Management, Department of Environmental Affairs and Tourism. October 1999. National Workshop on Planning for Development of Mariculture in South Africa. Sea Point Aquarium Cape Town.

McCarthy, J., Baxter, G., Schroenn, J., McGrath, M., Forbes, A. and Parnell, S., 1998. Coastal Economic Specialist Study, Coastal Management Policy Programme, Cape Town: The Department of Environmental Affairs and Tourism.

National Ports Authority. July 2002. Strategic Environmental Assessment for the Port of Cape Town. Phase One. Draft Scoping Report. 
Oberholzer, B., Boddington, G., and J. Grindley. July 1982. Design Guidelines for Coastal Urban, Recreational and Industrial Development. Proceedings from Coastal Ecology for Engineers, University of Stellenbosch.

Olsen, S., Lowry, K., Tobey, J., Burbridge P., and S. Humphrey. 1997. Survey of Current Purposes and Methods for Evaluating Coastal Management Projects and Programs Funded by International Donors. Coastal Management Report \#2200. The Coastal Resources Center, University of Rhode Island, Narragansett, Rhode Island.

PAWC (Provincial Administration Western Cape). 2002. Western Cape Fiscal Policy Statement.

Payne, A.I.L. and R.J.M. Crawford (Eds.) 1989. Oceans of Life off Southern Africa. Vlaeberg Publishers, Cape Town.

Pomeroy, R., Katon, B. and I. Harkes. 2001. Conditions affecting the success of fisheries comanagement: lessons from Asia. Marine Policy 25: 197-208.

Protected areas in South Africa. South African Journal of Marine Science. 18. 341-367.

PAWC (Provincial Administration Western Cape), Western Cape Fiscal Policy Statement, 2002.

Protected areas in South Africa. South African Journal of Marine Science. 18. 369-383.

Provincial Government of the Western Cape, Department of Environmental Affairs and Development Planning. March 2003. Coastal Zone Policy for the Western Cape. Dennis Moss Partnership inc. Stellenbosch

Provincial Government of the Western Cape, July 2001. Coastal Zone Policy of the Western Cape.

Provincial Government: Western Cape. 2003. Discussion Document Towards a Framework for Provincial Municipal Planning and Budgeting Alignment. 
Provincial Government of the Western Cape, White Paper Preparing the Western Cape for the Knowledge Economy of the $21^{\text {st }}$ century. Department of Economic Affairs, Agriculture and Tourism. Provincial Gazette Extraordinary No 5729 May 2001.

Robinson, G. A. and G. De Graaff. 1994. Marine Protected Areas of the Republic of South Africa. National Parks Board, Pretoria.

UNESCO Convention Concerning the Protection of the World Cultural and Natural Heritage (World Heritage Convention) 1972.

United Nations Convention on the Law of the Sea. 1982.

United Nations Framework Conventions on Climate Change (UNFCCC) 1992.

University of Rhode Island, Coastal Resources Center. 1998. Application of International Experience to formulation of a national policy for Coastal Management for the Republic of South Africa. Coastal Management Report, number 2206.

Wesgro, 2000: Wesgro Annual Report. Wesgro, Cape Town.

Western Cape Government: Strategic Framework for policy formulation. December 2001.

World Commission on Dams, 2000. Dams and Development: A new framework for decisionmaking. Earthscan Publications, UK.

\section{INTERNET REFERENCES}

www.imo.org

www.gpa.unep.org

www.londoncenvention.org

\section{PERSONAL COMMUNICATION}

$\begin{array}{ll}\text { W. Thomas } & \text { Wesgro } \\ \text { F. Fourie } & \text { MCM } \\ \text { L. Collier } & \text { MCM } \\ \text { G. Pitcher } & \text { MCM } \\ \text { T. Probyn } & \text { MCM }\end{array}$



R. Anderson
Seaweed Research Unit, UCT
R. Krohn
Hermanus Abalone Farm
E. van der Walt
Department of Minerals and Energy
B. Cilliers
National Ports Authority
K. Swart
Department of Agriculture
K. Brand
Department of Public Works
D. Impson
Western Cape Nature Conservation
D. Coleman
Council for Geoscience

SOME USEFUL ENVIRONMENTAL, PLANNING AND ADMINISTRATIVE URLS

http://www.environment.gov.za

Environmental Conservation Act, 1989 (Act 73 of 1989) (“ECA")

Environmental Impact Assessment Regulations, (Government Notices No. 1182 and 1183 of 5 September 1997) (EIA Regulations) and all the amendments and corrections thereto:

follow the links under:

http://www.lando.co.za/dlaidler/linksEnviro.htm

National Environmental Act, 1989 (Act 107 of 1998 ("NEMA")

http://wwww.environment.gov.za/PolLeg/Legislation

National Biodiversity Bill

http://www.environment.gov.za/PolLeg/Legislation/Biodiversity/PublishedBiodiversity $\underline{\text { Bill.DOC }}$

http://www.wri.org/wri/biodiv/gbs-iv.htm\#actions

Establishing A National Policy Framework for Biodiversity Conservation

http://www.nbi.ac.za/biodiversity/main.htm

Biodiversity Policy and Planning

NATIONAL STATE OF THE ENVIRONMENTAL REPORT - SOUTH AFRICA

Climatic and Atmospheric Change

http://www.ngo.grida.no/soesa/nsoer/issues/climate/refer.htm

\section{WESTERN CAPE DEPARTMENT OF ENVIRONMENTAL AFFAIRS \& DEVELOPMENT PLANNING}

http://wwwwesterncape.gov.za/environmental cultural affairs/default. asp

\section{Provincial planning and Development act and PDA Amendment Bill}

Follow the 'key planning Legislation' links under:

http://www.lando.co.za/dlaidler/LinksEnviro.htm 


\section{NATIONAL DEPARTMENT OF AGRICULTURE}

http://www.nda.agric.za/

Agricultural Legislation

Conservation of Agricultural Resources Act, 1983 (Act 43 of 1983) ("CARA")

Not available on the web.

Draft Sustainable Utilisation of Agricultural Resources Bill, 2003

http://www.nda.agrc.za/docs/legislation

Department of Arts and Culture

http://www.dme.gov.za/

New Minerals Act

http://www.dme..gov.za/home.asp?menu+main

Follow the link to "legislation" on the drop down menu under the menu item 'publications)

Department of Water Affairs and Forestry

http://www.dwaf.gov..za/default/asp

National Forest and Water Legislation, available on the legislation page of the Department of Water Affairs and Forestry

http://www.dwaf.gov.za/Documents/Default.asp?Legislation

National Forest Act - 1998 (No. 84 of 1998)

File format(s) available for download: $\underline{\operatorname{doc}} \underline{\mathrm{pdf}}$

National Veld and Forest Fire Act - 1998 (No. 101 of 1998)

File format(s) available for download: $\underline{\operatorname{doc}} \underline{\mathrm{pdf}}$

National Wet op Bosse - 1998 (No. 84 of 1998)

File format(s) available for download: $\underline{\mathrm{doc}} \underline{\mathrm{pdf}}$

National Wet op Veld - en Bosbrande - 1998 (No. 101 of 1998)

File format(s) available for download: $\underline{\mathrm{doc}} \underline{\mathrm{pdf}}$

National Water Act - 1998 (No. 36 of 1998)

File format(s) available for download: $\underline{\text { doc } \mathrm{pdf}}$

National Water Amendment Act - 1999 (No. 45 of 1999)

File format(s) available for download: $\underline{\mathrm{doc}} \underline{\mathrm{pdf}}$

National Water Amendment Bill - 1999

File format(s) available for download: $\underline{\mathrm{doc}} \underline{\mathrm{pdf}}$ 
Water Services Act - 1997 (No. 108 of 1997)

File format(s) available for download: $\underline{\operatorname{doc}} \underline{\mathrm{pdf}}$

National Department of Provincial and Local Government

http://www.dplg.gov.za

List all recent legislation including:

Local government: Municipal Systems Act, 2000 (Act 32 of 200)

Local Government: Municipal Structures Act, 1998 (Act 17 of 1998)

http://www.dplg.gov.za/Documents/Legislation/Acts.htm\#legislation/Ats

National Department of Justice\& Constitutional Development

http://www.doj.gov.za/index.html

Promotion of Access to Information Act, 2000 (Act 2 of 2000) (PAIA)

http://www.gov.za/gazette/acts/2000/a2-00.pdf

Promotion of Administrative Justice Act, 2000 (Act3 of 2000) (PAJA)

http://www.gov.za/gazette/acts/2000/a3-00.pdf 